\title{
Islamic glazed wares from ancient Termez (southern Uzbekistan). Raw materials and techniques
}

\author{
Judit Molera ${ }^{1}$, Verònica Martínez Ferreras ${ }^{2}$, Agnese Fusaro ${ }^{2}$, Josep M. Gurt Esparraguera ${ }^{2}$, \\ Mainardo Gaudenzi ${ }^{1}$, Shakir R. Pidaev ${ }^{3}$, Trinitat Pradell ${ }^{4}$
}

1. Universitat de Vic-Universitat Central de Catalunya

2. ERAAUB, Universitat de Barcelona

3. Institute of Fine Arts, Academy of Sciences of the Republic of Uzbekistan

4. Universitat Politècnica de Catalunya

\begin{abstract}
Ancient Termez, located on the southern border of Transoxiana/Mawarannahr, was an important pottery production centre during the Islamic period. Recent archaeological and archaeometric research carried out by the Spanish-Uzbek team evidenced the manufacture of glazed and unglazed vessels at the workshops found in the lower city (shahristan) and its suburbs (rabad). Glazed local products, mainly dated between the $9^{\text {th }}$ and $16^{\text {th }} / 17^{\text {th }}$ centuries, comprise slip-painted, underglaze and inglaze painted wares, splashed sgraffiato, and monochrome wares. The present study focuses on the chemical, mineralogical and petrographic examination of different types of glazed ceramics recovered at Termez excavations in order to identify the microstructure and composition of the glazes, the technological processes involved in their manufacture, and their evolution over the centuries. Thin polished sections were prepared and slips and glazes were analysed by optical microscopy (OM) and scanning electron microscopy (SEM). The results reveal that all the local/regional ceramics have a slip and a transparent glaze, with one exception. Colour decorations were applied over the slip, forming thinner or thicker layers depending on the desired final colour. Green (copper), red (iron) and brown/black (iron and in some cases iron plus manganese) pigments were used for the decorations. A high lead glaze was used in the ceramics found in the alluvial plain dating between the $9^{\text {th }}$ and the $11^{\text {th }}$ century, while an alkaline glaze is associated with ceramics collected in the shahristan dating between the $12^{\text {th }}$ and the $17^{\text {th }}$ century. An alumina rich clay mixed with lead oxide was used in the slip from the alluvial plain ceramics while the slip contained large quartz grains in the ceramics found in shahristan. Three imports from the Iraqi regions, a monochrome lustreware bowl and two white opaque glazed dishes dating from the $9^{\text {th }}-10^{\text {th }}$ centuries, were also recovered. They have the characteristic tinopacified mixed lead-alkali glazes and fine calcareous pastes.
\end{abstract}

Keywords: Termez; slips; lead glazes; alkaline glazes; ancient ceramics 


\section{Geographical and Historical introduction}

The site of ancient Termez is located in the southernmost limit of Uzbekistan, along the Oxus river or Amu Darya, lying $7 \mathrm{~km}$ south-east from the modern city. Its long history extended from the $3^{\text {rd }}-2^{\text {nd }}$ century $B C E$ to the $18^{\text {th }}$ century $C E$, with the Kushan $\left(1^{\text {st }} B C E-3^{\text {rd }}\right.$ century $\left.C E\right)$ and the Early Islamic $\left(9^{\text {th }}\right.$ century-1220) periods being the most flourishing phases (Leriche and Pidaev, $2007,2008)$. Since the Arab conquest in the late $7^{\text {th }}$ century CE, ancient Termez was part of the region of Transoxiana, known in Arabic as Mā warā' al-Nahr/Mawarannahr. It was defined as the lands under Muslim control lying to the north of the Amu Darya, in contrast to the Iranian lands proper.

In the $9^{\text {th }}-10^{\text {th }}$ centuries, under the Samanid dynasty, the city greatly developed and prospered, reaching the remarkable extension of 500 hectares. It consisted of three fortified areas, each with its own walls. The citadel (kohandez or ark) is in a higher position than the rest of the city, being located on a rectangular mound along the river bank. North-west of it, there is the proper city or shahristan, densely inhabited. The suburbs, or rabad, occupy the larger area of the city, lying east and north-east of both citadel and shahristan; markets, caravanserais, and manufacturing workshops concentrated in the rabad, being the centre of the economic life (Leriche and Pidaev, 2007).

After the fall of the Samanids, between the $11^{\text {th }}$ and the early $13^{\text {th }}$ century, ancient Termez was contested between several Central Asian dynasties, who alternatively controlled this powerful stronghold. During the $11^{\text {th }}$ century, the city and the lands surrounding Balkh were disputed between Kharakanids and Ghaznavids, the latter finally included them within their possessions. Around 1043-1044, the region came under the Seljuqs, that contributed to the further development of the city. Nonetheless, the Kharakhanids continuously tried to conquer those lands, with some success. From the mid- $12^{\text {th }}$ century, other powers began fighting each other for the control of this strategic site; the city was taken first by the Kara Khitays, by the Ghurids later and by the Khwarazm Shas in the first decade of the $13^{\text {th }}$ century. In 1220 the Mongols of Genghis Khan took and largely destroyed ancient Termez (Leriche and Pidaev, 2008). Nonetheless, the city was able to recover afterwards, as testified by several archaeological finds, both structures and materials, dated from the $13^{\text {th }}$ until the $17^{\text {th }} / 18^{\text {th }}$ century (Martínez Ferreras et al., 2019a).

Within the Mawarannahr, Termez was the major city of the Surkhan Darya valley. Indeed, its strategic position, at the confluence of this river with the Amu Darya, controlling the point where it is easier to cross the latter, gave the site a crucial political and military role, protecting the northern and southern boundaries of various political entities. Moreover, the city was located along one of the most important routes of the Silk Road, connecting Samarqand and Bukhara to the north with Balkh to the south, and from there to the Indian subcontinent; therefore, Termez also acquired an important commercial role, particularly during the $10^{\text {th }}-12^{\text {th }}$ centuries. This also affected the local craftsmanship, which became a leading activity in the economic life of the city. According to the historical sources, the city produced many different items, such as soaps, boats, metals and glasses, and it exported the herbal substance called 
asafoetida; ceramics should have been a well-developed manufacture, as Termez was also known for manufacturing jugs (Leriche and Pidaev, 2008: 117-118).

The archaeological research-works carried out so far, mainly by the Termez Archaeological Expedition (Pidaev, 1986) and by the MAFOuz team (Mission Archéologique Franco-Ouzbèke de Bactriane Septentrionale (Leriche et al., 2001), offer a quite comprehensive overview of the intense pottery production during the Islamic period at the site of ancient Termez. F. Lesguer (2015) recently published a synthesis of the ceramic workshops recovered in different areas of the city by previous archaeological missions. In 2018, the Uzbek-Spanish IPAEB team (International Pluridisciplinary Archaeological Expedition to Bactria) recovered new structures related to pottery manufacture. To date, a total of eight workshops and potter quarters dated to the Islamic period have been identified (Fig.1). In the extra-moenia area, north-west of the rabad and north of shahristan, there were four workshops; the northernmost one (no. 1) and the southernmost ones (nos 8 and 11) have one kiln, while workshop 2, close to the first one, has three kilns. From the archaeological evidence, it seems that workshops 1 and 2 mainly produced unglazed large containers. Workshop 8 was specialized in the production of glazed vessels and sphero-conical vessels; the latter are peculiar containers with a very narrow mouth, made of thick overfired ceramic body. Workshop 11, newly discovered by the IPAEB team, is probably connected with the production of unglazed fine jugs and sphero-conical vessels, but the kilns related to the latter manufacture have not yet been found. According to the pottery study and the $\mathrm{C}^{14}$ tests on organic material, these centres were active in the early Islamic period (i.e. $9^{\text {th }}-10^{\text {th }}$ century) (Martínez Ferreras et al., 2019a). In the northern part of the rabad, a workshop (no. 9) was specialized in manufacturing unglazed high-quality fine vessels. Sphero-conical vessels seem to be produced also in another workshop (no. 10) placed in the south-east sector of the rabad (Leriche and Pidaev, 2008: 109-114; Lesguer 2015: 435436). On the opposite side of the site, west of the citadel, very close to the river bank, the French-Uzbek MAFOuz team found a kiln (workshop 4) dated to the $11^{\text {th }}-12^{\text {th }}$ century (Lesguer, 2015). Inside the shahristan a workshop (no. 5) was discovered by the MAFOuz mission and is being re-examined by the Uzbek-Spanish team. It has at least three kilns and one wasters pit. Recent ${ }^{14} \mathrm{C}$ analysis carried out on several charcoal samples found within one of the kilns provided two different absolute dates between the early $14^{\text {th }}$ and mid-15 ${ }^{\text {th }}$ centuries AD: 1306 1363 cal AD (50.1\%); $1385-1429$ cal AD (45.3\%); it manufactured unglazed moulded relief decorated jugs and flasks but also underglaze painted wares and probably monochrome turquoise vessels, suggesting that this workshop already operated during the $13^{\text {th }}$ century $A D$ (Martínez Ferreras et al., 2019a; Fusaro et al., in press). 
The discovery of several pottery kilns, with the associated dumps, wasters and elements of potter's furniture, such as moulds for jugs and flasks, unquestionably prove that the city was a very active centre manufacturing ceramics, both unglazed and glazed, and sphero-conical vessels. Along with the production of a large quantity of unglazed vessels, especially fine jugs and flasks, that confirmed the information given by the historical sources, the production of glazed vessels took a distinguished place in the ceramic manufacture of Termez during the Islamic period. Recent archaeological and archaeometric investigations conducted by the IPAEB team have defined the morphological and stylistic features of the most common Islamic wares produced at Termez, also in comparison with other ceramic productions from important coeval Iranian and Central Asian sites. The preliminary geo-chemical, mineralogical, and petrographic characterisation of the ceramic pastes has also contributed to detect differences among local products, distinguish local and imported items, and determine the main technological processes related to their manufacture (Martínez Ferreras et al., 2019a; Fusaro et al., in press). This study demonstrates that ancient Termez produced a wide range of unglazed and glazed wares, also including high-quality artefacts, which equalled the ceramics produced in other important Central Asian centres. Especially between the $9^{\text {th }}$ and the $12^{\text {th }}$ century, during the most flourishing phase of the city, at least five workshops were active within and outside the rabad (nos 1, 2, 4, 8, 11). After the Mongol conquest of the city, even if its importance and size dramatically decreased, ancient Termez continued manufacturing ceramics, as testified by the potters' quarter no. 5 discovered inside the shahristan.

In order to complete the characterization of the glazed vessels, the present study focuses on the chemical, mineralogical and petrographic examination of different types of glazed surfaces to identify the composition of the materials, the glaze recipes, the technological processes involved in their manufacture, and their evolution over the centuries. The aim is giving a comprehensive and exhaustive description of the most important glaze techniques related to the vessels found at the site during the Islamic period, and better defining the contemporary imported items.

\section{Materials}

A total of 21 glazed earthenware vessels were selected for the analysis of the surface treatments. They come from two different archaeological contexts at the site of Termez and are dated between the $9^{\text {th }}$ and the $17^{\text {th }}$ century. Thirteen of them (coded TA) were collected in sector AC2 during the excavation carried out in 2009 by the Uzbek-Spanish team in the alluvial plain of Termez (Fig. 1) (Martínez Ferreras, 2010). This sounding, located in the westernmost sector of the site, has been interpreted as a rubbish dump used during the Islamic period. The complex stratigraphy of the dump stands on an ancient canal that connected the Surkhan Darya with the Amu Darya through Termez. The area was disturbed by modern activities, nonetheless the stratigraphic units, from which the selected ceramics come, remain untouched and can be considered reliable. Radiocarbon analysis and the examination of the ceramic assemblages suggest that the dump was formed between the $9^{\text {th }}$ and the $12^{\text {th }}$ centuries. The other eight ceramic samples (coded TS) come from the area of the kiln 1 within the pottery workshop 5 located in the shahristan and excavated in 2009 by Larisa Baratova, 
member of the MAFOuz team (Fig.1). They cover a timespan from the $10^{\text {th }} / 11^{\text {th }}$ to the $16^{\text {th }} / 17^{\text {th }}$ centuries AD. Their finding in the area of the workshop does not mean that these ceramics were produced there. Indeed, as mentioned above, the shahristan was a densely inhabited area, where the citizens of Termez lived at least since the $9^{\text {th }}-10^{\text {th }}$ century; pottery could have circulated in the area since the early Islamic period. The pottery workshop 5 was created later, and it has been dated from the $13^{\text {th }}$ century onwards (Martínez Ferreras et al., 2019a). Therefore, to date the provenance of at least some of the vessels analysed from this shahristan area cannot be directly attributed to the pottery workshop 5 .

The specimens selected and analysed provide a general overview of the wares circulating at ancient Termez during the Islamic period. Vessels from the rubbish dump stylistically belong to the slip-painted ware (TA3, TA8, TA11, TA12), the underglaze painted ware (TA2, TA5, TA9, TA10, TA13), and the splashed sgraffiato ware (TA4, TA7) (Fig. 2). Based on archaeological data, morphological and stylistic criteria, and $\mathrm{C}^{14}$ results, these vessels can be dated between the $9^{\text {th }}$ and the $11^{\text {th }}$ century. Less frequent wares are represented by a lustre-painted bowl (TA1) and an opaque white glazed dish (TA6) dated to the $9^{\text {th }}-10^{\text {th }}$ centuries. Vessels from the pottery workshop in the shahristan consist of monochrome glazed wares (TS3, TS5, TS6), one of them also bearing sgraffiato decoration (TS7), dated to the late $12^{\text {th }}-13^{\text {th }}$ century, and underglaze/inglaze painted bowls (TS4, TS8) attributed to the $14^{\text {th }} / 15^{\text {th }}$ and the $16^{\text {th }} / 17^{\text {th }}$ century, respectively. The earliest glazed vessels analysed from this area are an opaque white glazed dish with turquoise splashes (TS1) and a slip-painted vessel (TS2) (Martínez Ferreras et al., 2019a; Fusaro et al., in press).

The archaeometric characterisation of the selected glazed vessels previously conducted comprised the chemical analysis by wavelength Dispersive X-ray Fluorescence (WD-XRF), the mineralogical analysis by X-ray Diffraction (XRD) and the petrographic analysis through thinsection optical microscopy (OM) of the ceramic bodies. This investigation was carried out at the Scientific and Technological Centres of the University of Barcelona and allowed distinguishing three main groups of vessels (A, B and C), interpreted as local or regional products, and three imports (Table 1) (Martínez Ferreras et al., 2019a; Fusaro et al., in press).

Group A comprises glazed vessels from the shahristan area -the green monochrome (TS3), the turquoise monochrome (TS5, TS6 and TS7), and the underglaze/inglaze painted bowls (TS4, TS8) - dated between the $12^{\text {th }}$ and the $16^{\text {th }} / 17^{\text {th }}$ century (Fig. 2). Group B includes five vessels from the rubbish dump in the alluvial plain -two slip-painted bowls (TA3, TA11), a splashed sgraffiato bowl (TA7) and two underglaze painted bowls (TA5, TA10)-, attributed to the timespan of the $9^{\text {th }}-11^{\text {th }}$ centuries. Even if some chemical differences have been detected among the vessels classified in groups $A$ and $B$, all of them have been considered as local products. They consist of calcareous pastes ( $\mathrm{CaO}:$ 10-11 wt\%) with similar chemical composition to the local productions from Termez related to the pre-Islamic period (Tsantini et al., 2016; Martínez Ferreras et al., 2019b). Indeed, the mineralogical and petrographic composition of these vessels is consistent with the local raw materials (clayey sediments) also analysed from Termez and with the geological composition of the region.

Group C comprises underglaze painted (TA2, TA13), slip-painted (TA8, TA12) and splashed sgraffiato specimens (TA4) from the alluvial plain, dated between the $9^{\text {th }}$ and the $11^{\text {th }}$ century (Fig. 2). They have been attributed to a local-regional origin since their chemical composition slightly differs from that of the local products. Thus, these wares exhibit higher $\mathrm{Nb}, \mathrm{Zr}, \mathrm{Y}$ and 
Ga content than the vessels from the chemical groups A and B. Nevertheless, the petrographic composition is compatible with the geological environment of the city and that of the Amu Darya-Surkhan Darya floodplain. In some cases, their morphological-decorative features, recalling the productions of other Central Asian sites, support a different manufacturing centre within the region.

Within the assemblage analysed, the only sure imported items from farthermost lands are three vessels belonging to the opaque glazed wares, TA1 and TA6 recovered in sector AC2, and TS1 from shahristan (Fig. 2, Table 1). They are very fine calcareous fabrics and exhibit a significantly different chemical and petrographic composition with respect to the local-regional glazed vessels. TA1 is a bowl that belongs to the lustre-painted ware and it can be dated to the $9^{\text {th }}$ century, as suggested by its polychrome decoration and its form. It largely conforms to the lustre-painted production typical of the southern Iraqi area. This suggested provenance has been confirmed by the matching of its ceramic body with the Basra petrofabric (Frierman et al., 1979; Mason and Keall, 1991; Mason 1997a, 1997b, 2004; Mason and Tite, 1997; Pradell et al., 2008). TA6 and TS1 are two large shallow dishes with a wide everted flat rim, that can be dated to the $9^{\text {th }}-10^{\text {th }}$ centuries. They are completely covered with a well-opacified white glaze, TS1 is also characterized by smaller turquoise splashes dripping from the rim. The chemical compositions of the pastes differ from each other, thus suggesting two different productions. Especially the fabric of TA6 exhibits similar chemical composition to that of the plain opaque glazed wares from Samarra and Basra in Iraq (Mason and Keall, 1991; Mason, 1997a, 2004; Mason and Tite, 1997).

\section{Experimental methods}

To examine the surface coatings of the selected vessels, thin polished sections were prepared and glazes and slips were analysed by optical microscopy (OM) and scanning electron microscopy (SEM). The thin section of each sample was examined at the Universitat de Vic Universitat Central de Catalunya both in transmitted and reflected light with an optical microscope (OM, LEICA), and with a scanning electron microscope (SEM, GEMINI (Shottky FE) at the Universitat Politècnica de Catalunya. Glazes, slips and decorations were analysed by SEM-EDS (INCAPentaFETx3 detector, 30mm2, ATW2 window, resolution $123 \mathrm{eV}$ at the $\mathrm{Mn} \mathrm{K} \alpha$ energy line), operated at $20-\mathrm{kV}$ acceleration voltage with $1.1 \mathrm{~nm}$ lateral resolution, $20 \mathrm{nA}$ current, $7 \mathrm{~mm}$ working distance, and $120 \mathrm{~s}$ measuring times. The results were normalized and then averaged (totals of glaze varied between 98 and 102\%). The EDS elemental microanalysis system was calibrated with various oxide and minerals while for the lead a high-lead glass standard (K229, Geller Microanalytical Laboratory, MA, USA) was used. Typical detection limits are $0.1 \%$ for $\mathrm{Na}, \mathrm{Mg}, \mathrm{Al}, \mathrm{P}, \mathrm{K}, \mathrm{Ca}, \mathrm{Ti}$, and $\mathrm{Fe} ; 0.2$ for $\mathrm{Si}$ and $\mathrm{Cu} ; 0.3$ for $\mathrm{Sn}$; and 0.4 for $\mathrm{Pb}$. The microstructures of the glazes, slips and decorations layers were studied and recorded in back-scattered electron (BSE) mode in which the different phases present could be distinguished on the basis of their atomic number contrast. BSE images of the microstructures were obtained at $20 \mathrm{kV}$ acceleration voltages. 


\section{Results}

The analysis of the chemical composition of the glazes (Table 2) shows clear technological differences among the samples. All the local-regional specimens, with a single exception (TS3), have a slip under the glaze, either white or coloured, and all are covered with a transparent glaze; the three imported ceramics (TS1, TA1, TA6) are tin-glazed and none of them are slipped. Most of the local-regional ceramics found in the alluvial plain and dated to the $9^{\text {th }}-11^{\text {th }}$ centuries (TA2, TA3, TA4, TA5, TA7, TA8, TA9, TA10, TA11, TA12, TA13) as well as samples TS2 and TS3 from the shahristan, attributed to the $10^{\text {th }}-12^{\text {th }}$ centuries, are lead-glazed. Differently, the surfaces of the rest of the vessels from the shahristan dated to the $12^{\text {th }}-17^{\text {th }}$ centuries are alkaline-glazed (TS4, TS5, TS6, TS7, TS8). The compositional differences among the samples are clearly shown in the bivariant plots $\mathrm{Na}_{2} \mathrm{O}-\mathrm{PbO}$ and $\mathrm{Na}_{2} \mathrm{O}-\mathrm{K}_{2} \mathrm{O}$ of Fig. 3 .

\subsection{Ceramics with transparent Lead Glazes}

The ceramic vessels found in the alluvial plain and dated from the $9^{\text {th }}$ to the $11^{\text {th }}$ century, belonging to the slip-painted (TA3, TA8, TA11, TA12), underglaze painted (TA2, TA5, TA9, TA10, TA13), and splashed sgraffiato wares (TA4, TA7), as well as the slip-painted vessel TS2 $\left(10^{\text {th }}-\right.$ $11^{\text {th }}$ century) from the shahristan, have all the same characteristics. All of them have a white slip decorated with different colours and a transparent lead glaze over the slipped surface, the results of the chemical analysis of the glazes are shown in Table 2 and those of the slips in Table 3; bivariant plots $\mathrm{PbO}-\mathrm{SiO}_{2}$ and $\mathrm{Al}_{2} \mathrm{O}_{3}-\mathrm{SiO}_{2}$ of the slips are shown in Fig. 4. The glaze is lead-rich with 53 wt\% of $\mathrm{PbO}, 37 \mathrm{wt} \% \mathrm{SiO}_{2}$ and $2.5 \mathrm{wt} \%$ of $\mathrm{Al}_{2} \mathrm{O}_{3}$ as major components and low contents (below 2 wt\%) of $\mathrm{K}_{2} \mathrm{O}+\mathrm{Na}_{2} \mathrm{O}$ and $\mathrm{CaO}$. The microstructures of the glazes, slips, and decorations layers were studied and recorded with optical microscopy in reflected and polarised light and in back-scattered electron (BSE) mode. The glaze does not contain raw inclusions, neither bubbles, nor crystals developed at the interface between the glaze and the slip (Fig. 5), indicating that the glaze might have been applied in a second firing. This is to say that white slips were applied over the dried clay body and decorated previous to the first firing.

The thickness of the white slips varies between 40 and 70 microns (Fig. 5A). The slips were made using a rich aluminium clay with low $\mathrm{CaO}$ content. The content of $\mathrm{Al}_{2} \mathrm{O}_{3}$ (ranging from 16 to $25 \mathrm{wt} \%$ ) is higher than that found in the ceramic body (Table 3 and Fig. 4A). The slips also contain PbO varying between $10 \%$ and $22 \mathrm{wt} \%$. PbO should be considered as a component of the slip because the content is too high to be attributed exclusively to the interaction between glaze and slip (Table 3). The addition of PbO to the slip is a good practice because it helps the bonding with the ceramic body, which is important when a double firing is performed. Other fluxes such as $\mathrm{Na}_{2} \mathrm{O}$ (ranging from 0.9 to $2.8 \mathrm{wt} \%$ ) may also have been added to help the bonding of the slip with paste and glaze.

With respect to the composition of the glazes, it is possible to determine if $\mathrm{PbO}$ was applied directly over the slip or was previously mixed with sand and then applied over the slip. Figure $4 \mathrm{~B}$ shows the silica content of the glazes and of the slips after subtracting the $\mathrm{PbO}$ and renormalizing; the $\mathrm{SiO}_{2}$ of the glazes is above the dissolution line, indicating that a mixture of $\mathrm{PbO}+\mathrm{SiO}_{2}$ was used.

Decorations in green, red, brown, or yellow were applied over the slip and under the glaze. The green colour was made adding copper which appears completely dissolved into the glaze. 
The other colours appear over the slip forming a thin or sometimes a thick layer, and can be clearly seen with the Optical microscope. Those showing thin colour layers, such as TA2, were stylistically classified as underglaze painted while those with thick colour layers, such as TA3, as slip-painted ware. Fig. 5 (B) shows a thin layer of a red fine clay (rich in $\mathrm{Fe}_{2} \mathrm{O}_{3}$ ) applied over the white slip corresponding to the red-light brown decoration of sample TA2. The dark brown decoration of sample TA3 appears as a thick coarse layer of a red clay mixed with quartz and feldspars as is shown in the polarised light image of the cross section (Fig. 5C). On the contrary, the black decorations of all samples were obtained with a pigment made of large iron oxide particles (Fig. 5D) applied over the white slip. Although all the black decorations contain mainly iron oxides, some of them contain also particles of manganese oxide (TA10, TA11, TA12, TA13 and TS2). Iron (and manganese) oxide particles applied under the glaze tend to soar in the lead glaze, as it is observed in Fig. 5D.

In particular, bowl TA12 (Fig. 6) has a black slip completely covering the inner surface. The black slip contains large grains of iron oxide, some grains of a spinel with chromium (Fig. 6B) and partly dissolved grains of manganese oxide (Fig. 6A). Moreover, TA11 has a black epigraphic band which contains also large particles of iron oxides, neoformed hematite crystals and melanotekite crystals. According to Di Febo and others (2017), the presence of melanotekite and neoformed crystals of hematite indicates a glaze firing temperature below 925ㄷ.

In the case of the vessels with sgraffiato decoration (TA4 and TA7), incisions were made through the white slip where crystallites of diopside grew at the bottom of the glaze (Fig. 7) over the lead feldspars crystals formed at the interface. The slips and pigments used for the splashed sgraffiato ceramics are the same as those of the painted specimens commented before (Tables 2 and 3 ).

TS2 shows slight differences comparing with the rest of slip-painted and underglaze painted samples from the alluvial plain. The glaze is poorer in $\mathrm{PbO}(45 \mathrm{wt} \% \mathrm{PbO})$ and the black pigment is manganese-richer.

In summary, although corresponding to productions stylistically different (slip-painted, underglaze/inglaze painted or splashed sgraffiato wares) all the ceramics were produced using the following technique:

1. The vessel was first covered with a white clayey slip with one exception (a black slip for TA12)

2. The sgraffiato was made after applying the slip and before it was completely dry

3. The red or brown painted decorations were applied over the slip as a thin fine red clay or a thick layer coarse red clay, respectively. When they are thin, the ceramics are considered underglaze painted, on the contrary when they are thick the decoration is labelled slip-painted.

4. Black decorations were obtained with a pigment made of large iron oxide particles applied over the white slip, some of them contain also particles of manganese oxide or chromite.

5. The glaze was applied and fired in a second firing.

A recent study on underglaze painted and splashed sgraffiato ceramics from the Khurasan region, more specifically from Affrasiyab in Uzbekistan (Hoolakey et al 2019), and dated to the 
Samanid period $\left(9^{\text {th }}-10^{\text {th }} A D\right)$ shows that these are also covered with a lead glaze over a white slip; red and brown painted decorations were also made of iron and manganese oxides. Nonetheless, as the samples of this study have been analysed by non-invasive techniques, quantitative chemical analysis of the glazes and slips has not been obtained and cannot be compared with our data.

Bowl TS3 represents a different ware within the first glazed group from Termez: it is a monochrome glazed vessel characterised by a green lead glaze applied directly over the surface (Table 2). The glaze composition is not very different from the lead glazes of the other ceramics from the alluvial plain, but it does not have slip. The glaze has $2.7 \mathrm{wt} \%$ of copper mainly dissolved into the glaze and also some copper containing pyroxenes formed into the glaze (dark little crystals in the image of Fig. 8)

\subsection{Ceramics with Alkaline Glazes}

The ceramic vessels found at shahristan (TS4, TS5, TS6, TS7, TS8) have alkaline glazes $\left(\mathrm{Na}_{2} \mathrm{O}+\right.$ $\mathrm{K}_{2} \mathrm{O}>10$ wt\%), with high silica content (about 70 wt\% of $\mathrm{SiO}_{2}, 5$ wt $\%$ of $\mathrm{Al}_{2} \mathrm{O}_{3}, 4$ wt\% of $\mathrm{CaO}$ and $2 \mathrm{wt} \%$ of $\mathrm{MgO}$ ) (Table 2). They show bubbles across the glaze and some unreacted quartz grains. The alkaline glazes are more weathered and less well preserved than previous lead glazes. The glazes are between 100 and 200 microns thick, and are also applied over a white slip, but in this case the slip contains large quartz grains (Fig. 9) and therefore is silica richer but also richer in alkalis than the lead-glazed vessels. A comparison between the alkaline and the lead glazes compositions and their related white slips is shown in Table 4.

Copper is found dissolved into the alkaline glazes of samples TS5, TS6, TS7. Copper in rich sodium alkaline glazes gives a turquoise colour instead of green colour, which is typical of lead glazes.

The glaze of TS8 has a transparent alkaline glaze decorated in turquoise and black; the slip is richer in $\mathrm{SiO}_{2}$ than the earlier alkaline glazes as can be seen in Fig. 9 D-F. The black decoration is made of chromite grains with growing acicular yellow crystals around and which are identified as pyroxenes of $\mathrm{Na}-\mathrm{Ca}-\mathrm{Fe}-\mathrm{Cr}$.

Consequently, the ceramics of this period were also slipped, decorated and glazed, although the nature of the glazes and slips is different than the earliest local/regional productions.

\section{$\underline{4.3 \text { Imported vessels }}$}

Three imported vessels have been recognised: TA1, TA6, and TS1. They show opaque tin glazes with a mixed alkaline-lead composition. The samples do not have slips.

Bowl TA1 has a ceramic body composition similar to the Abbasid production from Iraq (Molina et al 2014) and it has the same low lead alkali glaze composition. Therefore, the glaze analysis confirms a provenance of the lustre-painted bowl from the Iraqi regions.

Dishes TA6 and TS1 also have tin-opacified mixed-alkaline lead glazes (Table 2). The archaeological and stylistical study of these specimens has already identified strong resemblance with items from Iraq, but also from Iran and Syria (Martínez Ferreras et al., 2019a). 


\section{Discussion}

The present study on the surface coatings of the selected glazed vessels from ancient Termez gives very interesting insights into the technology of the most widespread productions circulating at this site during the Islamic period.

The two well-defined technological groups, identified through the archaeometric analysis of slips and glazes, are consistent with the groups of wares recognised by the archaeological research-work, according to the examination of their morphological and decorative features. They represent two main chronological phases of the local/regional pottery production. The data obtained so far show that the technological tradition related to the manufacture of glazed vessels, especially concerning the slip and glaze recipes, clearly changed from the late $12^{\text {th }}$ early $13^{\text {th }}$ century. Indeed, the glazed wares produced before this moment, i.e. between the $9^{\text {th }}$ and the $11^{\text {th }}$ century, are characterized by clayey slips and high lead glazes, while the wares manufactured from the late $12^{\text {th }}$-early $13^{\text {th }}$ century onwards show slips very rich in quartz sand and alkaline glazes. Moreover, differences in the colours palettes of their decorations follow the fashion spread in each historical period: a large polychromy, including white, yellow, green, red, brown, black, is typical of the first group of wares; the second group is mainly associated with a colour scheme using turquoise, blue and black.

It is probable that this change in technology and fashion could be related to the Mongols' conquest of Termez in 1220, which deeply affected its daily life, including the artisanal activities. The archaeological research-work of the IPAEB team and the archaeometric study of the ceramics from Termez have revealed some repercussions of this shocking event on the pottery manufacture. First, as the city shrank, the pottery workshops moved from the suburbs to the shahristan, an urban area previously densely inhabited. Second, different raw materials, new techniques, new forms, and new motifs were introduced in the local pottery manufacture, in order to respond to a new economic and social order.

Especially the changes in fashion of the glazed earthenware vessels produced in the area of Termez could be possibly explained with the growing circulation and popularity of new highquality and more expensive ceramic items made of stonepaste, an artificial paste consisting in a mixture of crushed quartz, frit-glass, and white clay, that clearly imitates the porcelain body. Forms, colour palette, and decorative motifs of the vessels from Termez dated to the $12^{\text {th }} / 13^{\text {th }}$ $17^{\text {th }}$ century are strongly influenced by the features of these stonepaste vessels, spread in Central Asian and Iranian regions since the late $12^{\text {th }}$ century. Therefore, it is possible to suggest that the slips rich in quartz sand were produced to imitate the stonepaste body, while the use of blue/turquoise and black was influenced by the underglaze painted decoration of the stonepaste vessels, such as the Blue and White ware, that became widespread especially from the Timurid period.

The fruitful combination of the archaeological study and the archaeometric examination of pastes and surface coatings of the glazed samples from ancient Termez also allow proposing the provenance of the imported items. At least two of them, i.e. the lustre-painted bowl TA1 and the opaque white glazed dish TA6, most probably came from manufacturing centres located in the Iraqi regions, thus testifying to the role of Termez as an important trading post along Central Asian routes. In some cases, the arrival of these imports at Termez seems to have influenced the local production, as suggested by the specimen TA3: its decoration, consisting of palmette motifs painted in different brown hues, recalls that of the lustre-painted vessels although it is obvious that the potters did not known the secret of lustre. Therefore, it 
is possible that some local potters, specialized in producing slip-painted ware, tried to imitate imported luxury items from Iraq by using raw materials and techniques at their disposals; they possibly ignored the secret of the glaze opacification, even if there exist tin sources in Uzbekistan (in the area of Karnab, at about $450 \mathrm{~km}$ north of Termez, see for example Kaniuth 2007).

\section{Conclusions}

The ceramic vessels, of local or regional provenance, found in the alluvial plain of Termez and dated from the $9^{\text {th }}$ to the $11^{\text {th }}$ century have lead transparent glaze over a clayey slip. Colour decorations were applied over the slip, forming thinner or thicker layers depending on the painting technique chosen. Green (copper), red (iron) and brown/black (iron and in some cases iron plus manganese) pigments were used for the decorations. The slips were made with a rich-alumina clay mixed with lead oxide.

Ceramics collected in the shahristan dating between the $12^{\text {th }}$ and the $17^{\text {th }}$ century were made with alkaline glazes over white slips which contained large quartz grains and feldspars.

It is probable that this change in technology and fashion could be related to the Mongols' conquest of Termez in 1220and the effects it had on the city life.

In conclusion, even if the vessels analysed represent a small sampling and more analysis are needed, the present study can be considered an important contribution to the technological characterisation of the Central Asian pottery productions of the Islamic period. From a stylistical point of view, the transformation to which the local/regional glazed manufacture from Termez underwent has been detected also in other Central Asian sites (e.g. Balkh, Ghazni, Samarqand); nonetheless, to date this phenomenon, and its technological aspects, has been insufficiently studied and discussed by using an archaeometric approach, with a few exceptions (see, for example, Fusaro 2014).

The preliminary hypotheses so far proposed are interesting starting points that will be further investigated and verified by the future researches and results of this study, which is still in progress.

\section{Acknowledgments}

This study was carried out as part of the research conducted by V. Martínez Ferreras within the Ramón y Cajal program (RYC-2014-15789) funded by the Spanish Ministerio de Economía y Competitividad (MINECO). Financial support for research for this paper was provided by two research projects led by V. Martínez Ferreras (CAMOTECCER HAR2012-32653 and CERAC HAR2016-75133-C3-1-P) and funded by MINECO and also MAT2016-N0748719-R project funded by MINECO.

\section{References}

Di Febo, R., Molera, J., Pradell, T., Vallcorba, O. Capelli, C., 2017. Technological implications of neo-formed hematite crystals in ceramic lead glazes. STAR: Science \& Technology of Archaeological Research, vol 3, issue 2, 366-375. 
Frierman, J.D., Asaro, F., Michel, H.V., 1979. The Provenance of Early Islamic Lustre Wares. Ars Orientalis, 11, 111-126.

Fusaro, A., 2014. Studio del corpus ceramico di età islamica dagli scavi italiani a Ghazni, Afghanistan (X-XIII secolo): contributo alla ricostruzione storica del palazzo sultaniale e della "casa dei lustri.". PhD dissertation, "Sapienza" Università di Roma, Rome.

Fusaro, A., Martínez Ferreras, V., Gurt Esparraguera, J.M., Angourakis, A., Pidaev, S.R., Baratova, L., In Press. Islamic Pottery from Ancient Termez (Uzbekistan): New Archaeological and Archaeometric Data. Archeosciences.

Holakooei, P, de Lapérouse, J.F., Carò, F., Röhrs, S, Frankee, U., Müller-Wiener,M., Reiche, I., 2019. Non-invasive scientific studies on the provenance and technology of early Islamic ceramics from Afrasiyab and Nishapur. Journal of Archaeological Science: Reports, 24, 759-772

Gurt Esparraguera, J.M., and S.R. Pidaev, (Eds.), 2010. Preliminary Report of the Work of the International Pluridisciplinary Archaeological Expedition to Bactria 2009, IPAEB, vol. 4. Universitat de Barcelona, Barcelona.

Kaniuth, K., 2007. The metallurgy of the late bronze age Sapalli culture (Southern Uzbekistan) and its Implications for the 'tin question'. Iranica Antiqua, XLII, 23-40.

Leriche, P., Pidaev, S.R., Gelin, M., Abdoullaev, K. (Eds.), with the collaboration of Vincent Fourniau, 2001. La Bactriane au carrefour des routes et des civilisations de l'Asie Centrale: Termez et les villes de Bactriane-Tokharestan: actes du colloque de Termez 1997. IFEAC and Maisonneuve et Larose, Paris.

Leriche, P., Pidaev, S.R. 2007. Termez in antiquity, in: Cribb, J., Herrmann, G. (Eds.), After Alexander: Central Asia before Islam, Proceedings of the British Academy, 133, Oxford University Press, New York, pp. 179-211.

Leriche, P., Pidaev, S.R., 2008. Termez sur Oxus. Cité-capitale d'Asie Centrale. IFEAC and Maisonneuve et Larose [Publication AURORHE $n^{\circ} 3$ ], Paris.

Lesguer, F., 2015. Les fours de potiers à Termez (Ouzbékistan) du IV siècle au XII après J.-C., in: Thuillier, F., Louis, É. (Eds.), Tourner autour du pot. Les ateliers de potiers médiévaux du Ve au XIle siècle dans l'espace européen. Actes du colloque international de Douai (5-8 octobre 2010). Publications du Craham, Presses Universitaires de Caen, Caen, pp. 433-437.

Martínez Ferreras, V., 2010. Archaelogical excavation of Sector AC2 at Ancient Military Quarters (Termez), in: Gurt Esparraguera, J.M., S.R. Pidaev (Eds.), Preliminary report of the work of the International Pluridisciplinary Archaeological Expedition to Bactria 2009, IPAEB, vol. 4, Universitat de Barcelona, Barcelona, pp. 125-221.

Martínez Ferreras, V., Fusaro, A., Gurt Esparraguera, J.M., Ariño Gil, E., Pidaev, Sh.R., Angourakis, A., 2019a. The Islamic Ancient Termez Through the Lens of Ceramics: A New Archaeological and Archaeometric Study, Iran. Journal of the British Institute for Persian Studies, published online. https://doi.org/10.1080/05786967.2019.1572430 
Martínez Ferreras, V., Angourakis, A., Hein, A., Aulinas-Juncà, M., García-Vallés, M., Gurt Esparraguera, J.M., Ariño Gil, E., Sánchez del Corral, A., Pidaev, S.R., 2019b. Assessing Hellenistic to nomadic cultural patterns through pottery in ancient Termez, Uzbekistan, Geoarchaeology, 34, 540-564.

Mason, R.B., 1997a. Early mediaeval Iraqi lustre-painted and associated wares: Typology in a multidisciplinary study, Iraq, 59, 15-61.

Mason, R.B., 1997b. Medieval Egyptian Lustre-painted and Associated Wares: Typology in a Multidisciplinary Study, Journal of the American Research Center in Egypt, 34, 201-242.

Mason, R.B., 2004. Shine like the sun. Lustre-painted and associated pottery from the Medieval Middle East. Costa Mesa, Mazda Publishers and Royal Ontario Museum, Toronto.

Mason, R.B., Keall, E.T., 1991. The 'Abbāsid glazed wares of Sīrāf and the Bașra connection: Petrographic Analysis, Iran, 29, 51-66.

Mason, R.B., Tite, M.S., 1997. The beginnings of the tin-opacification of pottery glazes, Archaeometry, 39, 41-58.

Molina G., Tite, M.S., Molera, J., Climent-Font, A., Pradell, T., 2014, Technology of production of polychrome lustre. Journal of the European Ceramic Society, 34, 2563-2574.

Pidaev, S.R., 1986. Hozâistvenno-žiloy kompleks XI-načala XIII vekov na gorodišče Starogo Termeza [An artisanal and habitational complex of the 11th-beginning of the 12th century at the site of the ancient Termez]. ASU 11, 8-10.

Pradell, T., Molera, J., Smith, A.D., Tite, M.S., 2008. The invention of lustre: Iraq 9th and 10th centuries AD, Journal of Archaeological Science, 35, 1201-1215.

Tsantini, E., Martínez Ferreras, V., Ariño Gil, E., Gurt Esparraguera, J.M., Pidaev, S.R.. 2016. Pottery production in the Buddhist communities in Central Asia: The Kushan-Sassanian pottery workshop of Kara Tepe (Termez, Uzbekistan), Archaeometry, 58(1), 35-56. 
Tables

Table 1. Classification of the glazed vessels analysed according to the chemical (WD-XRF) and petrographic groups identified, with indication of their location, the proposed chronology and the estimated firing temperature of the body (EFT) determined through XRD (Martínez Ferreras et al., 2019a)

\begin{tabular}{|c|c|c|c|c|c|}
\hline PROVENANCE & SITE & DATE & SAMPLES & EFT & WARE \\
\hline \multirow{6}{*}{$\begin{array}{l}\text { LOCAL } \\
\text { Group A }\end{array}$} & \multirow{6}{*}{$\begin{array}{l}\text { Alluvial } \\
\text { plain and } \\
\text { shahristan }\end{array}$} & \multirow{2}{*}{$9^{\text {th }}-11^{\text {th }} \mathrm{c}$} & TA9 & $800-900^{\circ} \mathrm{C}$ & Underglaze painted \\
\hline & & & TS2 & $1000-1100^{\circ} \mathrm{C}$ & Slip-painted \\
\hline & & \multirow{2}{*}{$12^{\text {th }}-13^{\text {th }} \mathrm{c}$} & TS5 & $900-1000^{\circ} \mathrm{C}$ & \multirow{2}{*}{ Monochrome (green \& turquoise) } \\
\hline & & & TS3, TS6, TS7 & $1000-1100^{\circ} \mathrm{C}$ & \\
\hline & & $14^{\text {th }}-15^{\text {th }} \mathrm{c}$. & TS4 & $1000-1100^{\circ} \mathrm{C}$ & \multirow{2}{*}{ Underglaze/inglaze painted } \\
\hline & & $16^{\text {th }}-17^{\text {th }} \mathrm{c}$. & TS8 & $1000-1100^{\circ} \mathrm{C}$ & \\
\hline \multirow{3}{*}{$\begin{array}{l}\text { LOCAL } \\
\text { Group B }\end{array}$} & \multirow{3}{*}{$\begin{array}{l}\text { Alluvial } \\
\text { plain }\end{array}$} & \multirow{3}{*}{$9^{\text {th }}-11^{\text {th }} \mathrm{c}$. } & TA5, TA10 & $800-900^{\circ} \mathrm{C}$ & Underglaze painted \\
\hline & & & TA3, TA11 & $900-1000^{\circ} \mathrm{C}$ & Slip-painted \\
\hline & & & TA7 & $900-1000^{\circ} \mathrm{C}$ & Splashed sgraffiato \\
\hline \multirow{5}{*}{$\begin{array}{l}\text { LOCAL- } \\
\text { REGIONAL } \\
\text { Group C }\end{array}$} & \multirow{5}{*}{$\begin{array}{l}\text { Alluvial } \\
\text { plain }\end{array}$} & \multirow{5}{*}{$9^{\text {th }}-11^{\text {th }} \mathrm{c}$. } & TA2 & $800-900^{\circ} \mathrm{C}$ & \multirow{2}{*}{ Underglaze painted } \\
\hline & & & TA13 & $1000-1100^{\circ} \mathrm{C}$ & \\
\hline & & & TA8 & $900-1000^{\circ} \mathrm{C}$ & \multirow{2}{*}{ Slip-painted } \\
\hline & & & TA12 & $1000-1100^{\circ} \mathrm{C}$ & \\
\hline & & & TA4 & $1000-1100^{\circ} \mathrm{C}$ & Splashed sgraffiato \\
\hline \multirow{2}{*}{ IMPORTS } & \multirow{2}{*}{$\begin{array}{l}\text { Alluvial } \\
\text { plain and } \\
\text { shahristan }\end{array}$} & \multirow{2}{*}{$9^{\text {th }}-10^{\text {th }} \mathrm{c}$. } & TA1 & $1000-1100^{\circ} \mathrm{C}$ & Lustre painted \\
\hline & & & TA6, TS1 & $1000-1100^{\circ} \mathrm{C}$ & Opaque white glazed \\
\hline
\end{tabular}


Table 2. Chemical analysis of the ceramic glazes (TA and TS) through SEM-EDS

\begin{tabular}{|c|c|c|c|c|c|c|c|c|c|c|c|c|c|}
\hline Ref. & Chronology & $\mathrm{Na}_{2} \mathrm{O}$ & MgO & $\mathrm{Al}_{2} \mathrm{O}_{3}$ & $\mathrm{SiO}_{2}$ & $\mathrm{~K}_{2} \mathrm{O}$ & $\mathrm{CaO}$ & MnO & $\mathrm{FeO}$ & $\mathrm{CuO}$ & $\mathrm{SnO}_{2}$ & $\mathrm{PbO}$ & Type \\
\hline TA1 & 9-10th & 7.3 & 4.0 & 1.3 & 68.4 & 4.0 & 5.0 & 0.5 & 0.3 & b.d & 5.1 & 4.9 & Tin glaze \\
\hline TA6 & 9-11th & 2.8 & 0.9 & 2.1 & 52.1 & 4.0 & 2.6 & b.d & 0.5 & b.d & 5.6 & 29.6 & Tin glaze \\
\hline TS1 & 9-10th & 2.4 & 0.8 & 2.1 & 48.5 & 3.4 & 2.6 & b.d & 1.4 & b.d & 4.8 & 34.4 & Tin glaze \\
\hline TA5 & 9-10th & 1.0 & 0.3 & 3.6 & 38.6 & 0.6 & 1.1 & 0.1 & 1.8 & 0.6 & b.d & 52.4 & Lead Glaze \\
\hline TA10 & 9-10th & 0.8 & 0.4 & 2.0 & 36.9 & 0.5 & 1.3 & 0.8 & 1.7 & b.d & b.d & 55.8 & Lead Glaze \\
\hline TA11 & 9-10th & 0.5 & 0.3 & 1.8 & 34.7 & 0.4 & 1.7 & 1.1 & 4.0 & b.d & b.d & 55.4 & Lead Glaze \\
\hline TA3 & 10-11th & 0.7 & 0.2 & 2.4 & 38.1 & 0.5 & 1.1 & 0.3 & 0.5 & 0.4 & b.d & 53.1 & Lead Glaze \\
\hline TA7 & 10-11th & 0.7 & 0.6 & 2.2 & 39.9 & 0.7 & 2.2 & b.d & 0.6 & 2.9 & b.d & 49.9 & Lead Glaze \\
\hline TA8 & 9-10th & 1.3 & 0.4 & 1.6 & 36.4 & 2.0 & 1.3 & 0.3 & 5.3 & b.d & b.d & 51.6 & Lead Glaze \\
\hline TA2 & 9-11th & 0.9 & 0.4 & 1.7 & 36.4 & 0.5 & 1.1 & 0.1 & 0.6 & 0.2 & 0.2 & 58.1 & Lead Glaze \\
\hline TA13 & 9-11th & 1.3 & 0.8 & 3.1 & 50.5 & 2.7 & 2.0 & 0.0 & 0.9 & 0.0 & b.d & 38.8 & Lead Glaze \\
\hline TA12 & 10th & 1.0 & 0.6 & 2.8 & 35.7 & 1.2 & 1.8 & 2.2 & 5.8 & 0.2 & b.d & 48.7 & Lead Glaze \\
\hline TA4 & 10-11th & 1.1 & 0.6 & 2.4 & 39.1 & 1.0 & 1.7 & b.d & 0.9 & 1.0 & b.d & 52.2 & Lead Glaze \\
\hline TA9 & 9-11th & 0.3 & 0.2 & 5.0 & 37.4 & 0.6 & 2.9 & b.d & 0.9 & b.d & b.d & 52.8 & Lead Glaze \\
\hline TS2 & 10-11th & 1.4 & 0.6 & 3.7 & 41.1 & 1.8 & 1.8 & 0.8 & 3.4 & 0.2 & b.d & 45.3 & Lead Glaze \\
\hline TS3 & 11-12th & 0.7 & 0.5 & 2.7 & 33.9 & 1.1 & 3.0 & 0.0 & 1.2 & 2.7 & b.d & 54.1 & Lead Glaze \\
\hline TS5 & 12-13th & 12.3 & 2.2 & 3.4 & 67.7 & 4.4 & 3.7 & 0.0 & 0.8 & 5.1 & b.d & 0.1 & Alkaline Glaze \\
\hline TS6 & 12-13th & 8.7 & 2.1 & 4.3 & 68.7 & 5.8 & 4.3 & 0.3 & 1.0 & 4.1 & b.d & 0.3 & Alkaline Glaze \\
\hline TS7 & 12-13th & 7.1 & 2.5 & 4.5 & 74.2 & 5.4 & 4.8 & b.d & 0.5 & b.d & b.d & 0.2 & Alkaline Glaze \\
\hline TS4 & 14-15th & 8.0 & 1.5 & 11.0 & 67.1 & 7.3 & 2.7 & 0.3 & 0.5 & 0.7 & b.d & 0.2 & Alkaline Glaze \\
\hline TS8 & $16-17$ th & 7.2 & 2.9 & 2.7 & 68.2 & 3.8 & 5.0 & b.d & 7.9 & 1.6 & b.d & 0.0 & Alkaline Glaze \\
\hline
\end{tabular}


Table 4. Mean and standard deviation of Alkaline and Lead glazes and their slips renormalizing the composition after removing the colourants (copper, iron and manganese).

\begin{tabular}{cccccccccc}
\hline Ref. & Chronology & Arch. Context & $\mathrm{Na}_{2} \mathrm{O}$ & $\mathrm{K}_{2} \mathrm{O}$ & $\mathrm{Al}_{2} \mathrm{O}_{3}$ & $\mathrm{SiO}_{2}$ & $\mathrm{MgO}$ & $\mathrm{CaO}$ & $\mathrm{PbO}$ \\
\hline Lead Glaze & \multirow{2}{*-11th}{} & alluvial plain & 0.9 & 1.0 & 2.7 & 39.8 & 0.5 & 1.7 & 53.7 \\
& & std & 0.3 & 0.7 & 1.0 & 3.9 & 0.2 & 0.6 & 5.1 \\
\hline Alkaline Glaze & \multirow{2}{*}{ 12-17th } & shahristan & 9.2 & 5.6 & 5.4 & 73.0 & 2.4 & 4.3 & 0.2 \\
& & std & 2.3 & 1.3 & 3.3 & 2.9 & 0.6 & 1.1 & 0.1 \\
\hline \multirow{2}{*}{ Lead rich Slip } & \multirow{2}{*}{ 9-11th } & alluvial plain & 1.8 & 3.7 & 22.5 & 51.7 & 0.5 & 1.8 & 17.9 \\
& & std & 0.5 & 1.3 & 3.3 & 4.2 & 0.2 & 0.5 & 4.5 \\
\hline \multirow{2}{*}{ Quartz rich Slip } & \multirow{2}{*}{ 12-17th } & shahristan & 4.0 & 4.5 & 11.2 & 78.2 & 0.6 & 1.5 & - \\
& & std & 1.3 & 1.9 & 5.2 & 8.5 & 0.3 & 1.2 & - \\
\hline
\end{tabular}


Table 3. Chemical analysis of slips (TA and TS) through SEM-EDS

\begin{tabular}{|c|c|c|c|c|c|c|c|c|c|c|c|c|}
\hline Ref. & Chronology & $\mathrm{Na}_{2} \mathrm{O}$ & MgO & $\mathrm{Al}_{2} \mathrm{O}_{3}$ & $\mathrm{SiO}_{2}$ & $\mathrm{~K}_{2} \mathrm{O}$ & $\mathrm{CaO}$ & $\mathrm{MnO}$ & $\mathrm{FeO}$ & $\mathrm{CuO}$ & $\mathrm{PbO}$ & Type \\
\hline TA5 & 9-10th & 2.8 & 0.3 & 24.0 & 51.2 & 2.8 & 1.4 & b.d & 0.9 & 0.1 & 16.2 & Lead Glaze \\
\hline TA10 & 9-10th & 1.5 & 0.6 & 15.9 & 55.6 & 2.0 & 2.3 & 0.2 & 2.6 & 0.3 & 18.0 & Lead Glaze \\
\hline TA11 & 9-10th & 1.1 & 0.7 & 19.0 & 53.0 & 2.2 & 1.1 & 0.1 & 1.1 & b.d & 21.9 & Lead Glaze \\
\hline TA3 & 10-11th & 1.8 & 0.2 & 24.8 & 50.1 & 2.6 & 1.3 & b.d & 0.5 & b.d & 17.8 & Lead Glaze \\
\hline TA7 & 10-11th & 2.0 & 0.4 & 18.7 & 50.3 & 2.6 & 1.9 & b.d & 1.0 & 0.5 & 22.2 & Lead Glaze \\
\hline TA8 & 9-10th & 1.8 & 0.8 & 23.0 & 46.1 & 4.8 & 0.6 & b.d & 0.9 & 0.1 & 21.3 & Lead Glaze \\
\hline TA2 & 9-11th & 1.6 & 0.4 & 25.2 & 56.7 & 5.6 & 1.5 & b.d & 0.4 & b.d & 8.2 & Lead Glaze \\
\hline TA13 & 9-11th & 2.0 & 0.6 & 26.1 & 42.7 & 4.9 & 1.1 & b.d & 1.6 & b.d & 20.0 & Lead Glaze \\
\hline TA12 & 10th & 1.3 & 0.5 & 17.5 & 44.5 & 4.2 & 1.3 & 2.3 & 10.1 & b.d & 17.5 & Lead Glaze \\
\hline TA4 & 10-11th & 2.3 & 0.3 & 22.5 & 51.4 & 3.7 & 1.4 & b.d & 0.4 & 0.3 & 16.7 & Lead Glaze \\
\hline TA9 & 9-11th & 0.9 & 1.0 & 24.5 & 50.8 & 3.8 & 5.6 & b.d & 1.3 & b.d & 11.2 & Lead Glaze \\
\hline TS2 & 10-11th & 1.5 & 0.7 & 15.2 & 47.2 & 4.0 & 3.3 & 3.1 & 12.6 & b.d & 10.0 & Lead Glaze \\
\hline TS5 & 12-13th & 3.6 & 0.8 & 14.3 & 73.5 & 3.3 & 3.1 & b.d & 1.3 & b.d & 0.0 & Alkaline Glaze \\
\hline TS6 & 12-13th & 4.6 & 0.7 & 11.2 & 73.4 & 6.1 & 2.1 & b.d & 1.0 & 1.0 & 0.0 & Alkaline Glaze \\
\hline TS7 & 12-13th & 3.7 & 0.2 & 12.5 & 79.1 & 4.0 & 0.3 & b.d & 0.2 & b.d & 0.0 & Alkaline Glaze \\
\hline TS4 & 14-15th & 5.6 & 1.0 & 15.0 & 69.7 & 6.5 & 1.4 & b.d & 0.4 & b.d & 0.0 & Alkaline Glaze \\
\hline TS8 & 16-17th & 2.1 & 0.3 & 2.3 & 89.8 & 2.1 & 0.5 & b.d & 2.9 & 0.1 & 0.0 & Alkaline Glaze \\
\hline
\end{tabular}


Table 4. Mean and standard deviation of Alkaline and Lead glazes and their slips renormalizing the composition after removing the colourants (copper, iron and manganese).

\begin{tabular}{cccccccccc}
\hline Ref. & Chronology & Arch. Context & $\mathrm{Na}_{2} \mathrm{O}$ & $\mathrm{K}_{2} \mathrm{O}$ & $\mathrm{Al}_{2} \mathrm{O}_{3}$ & $\mathrm{SiO}_{2}$ & $\mathrm{MgO}$ & $\mathrm{CaO}$ & $\mathrm{PbO}$ \\
\hline Lead Glazes & 9-11th & $\begin{array}{c}\text { alluvial plain } \\
\text { std }\end{array}$ & 0.9 & 1.0 & 2.7 & 39.8 & 0.5 & 1.7 & 53.7 \\
& & 0.3 & 0.7 & 1.0 & 3.9 & 0.2 & 0.6 & 5.1 \\
\hline $\begin{array}{c}\text { Slip under Lead } \\
\text { Glazes }\end{array}$ & \multirow{2}{*}{ 9-11th } & alluvial plain & 1.8 & 3.7 & 22.5 & 51.7 & 0.5 & 1.8 & 17.9 \\
& & std & 0.5 & 1.3 & 3.3 & 4.2 & 0.2 & 0.5 & 4.5 \\
\hline Alkaline Glazes & $\mathbf{1 2 - 1 7 t h}$ & shahristan & 9.2 & 5.6 & 5.4 & 73.0 & 2.4 & 4.3 & 0.2 \\
& & std & 2.3 & 1.3 & 3.3 & 2.9 & 0.6 & 1.1 & 0.1 \\
\hline $\begin{array}{c}\text { Slip under } \\
\text { alkaline Glazes }\end{array}$ & \multirow{2}{*}{ 12-17th } & shahristan & 4.0 & 4.5 & 11.2 & 78.2 & 0.6 & 1.5 & - \\
& & std & 1.3 & 1.9 & 5.2 & 8.5 & 0.3 & 1.2 & - \\
\hline
\end{tabular}


Figures

Fig.1

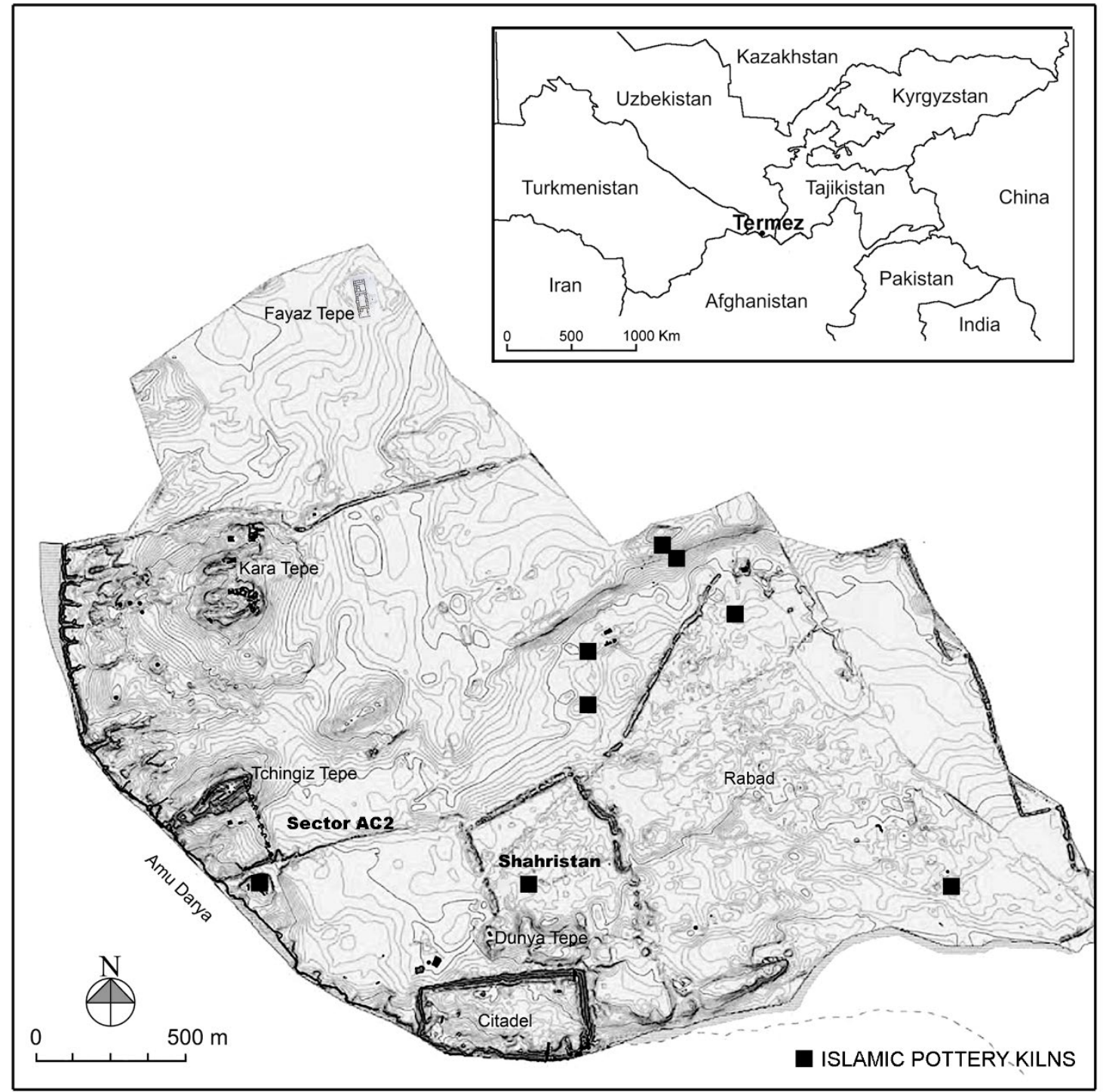

Fig. 1. The location and general layout of Ancient Termez (from Leriche and Pidaev 2007: 183, fig. 2), with the indication of the Islamic pottery workshops. 

Fig.2

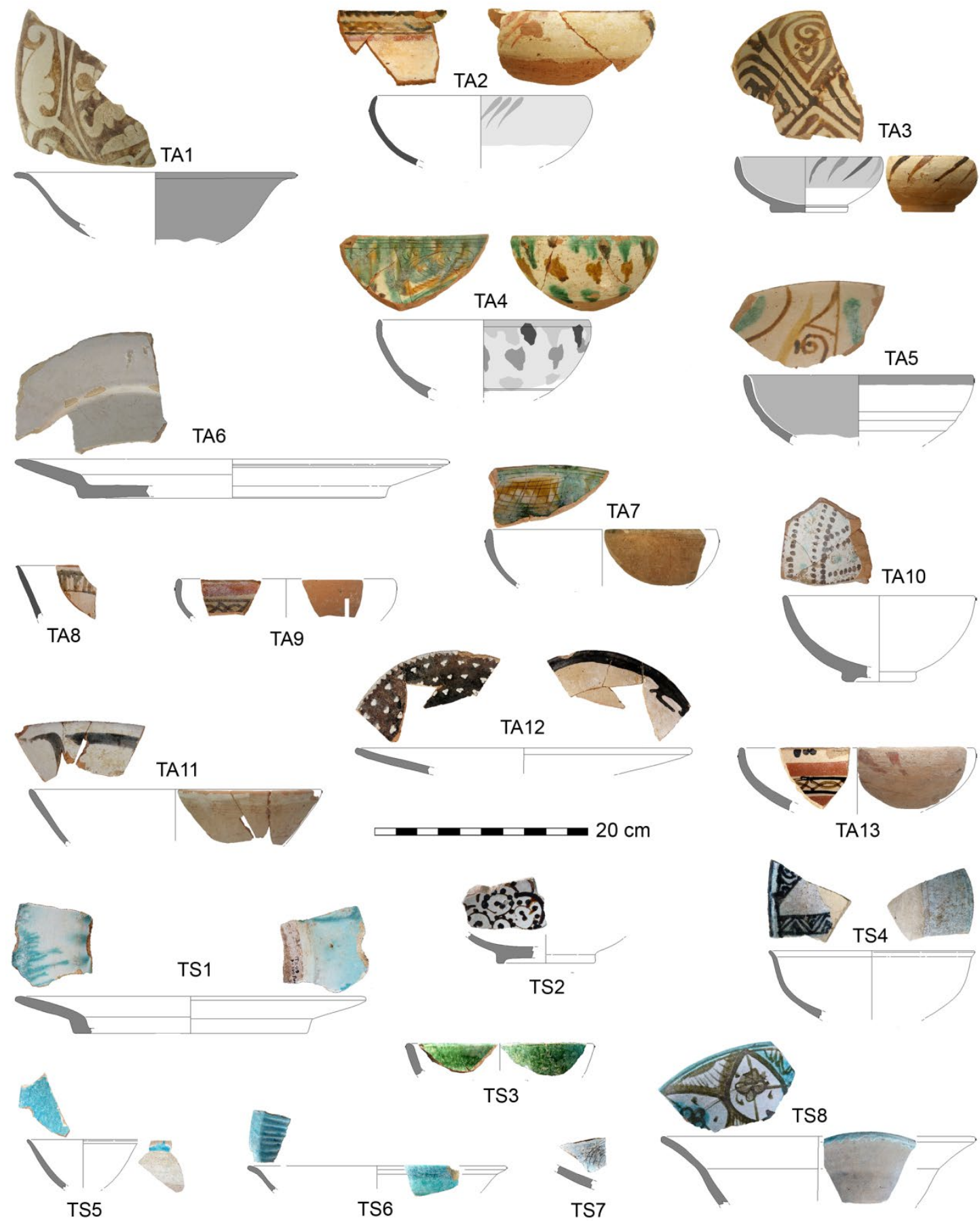

Fig. 2. Glazed vessels analysed from the rubbish dump in the alluvial plain (coded TA) and from the pottery workshop in the shahristan (coded TS) 
Figure 3
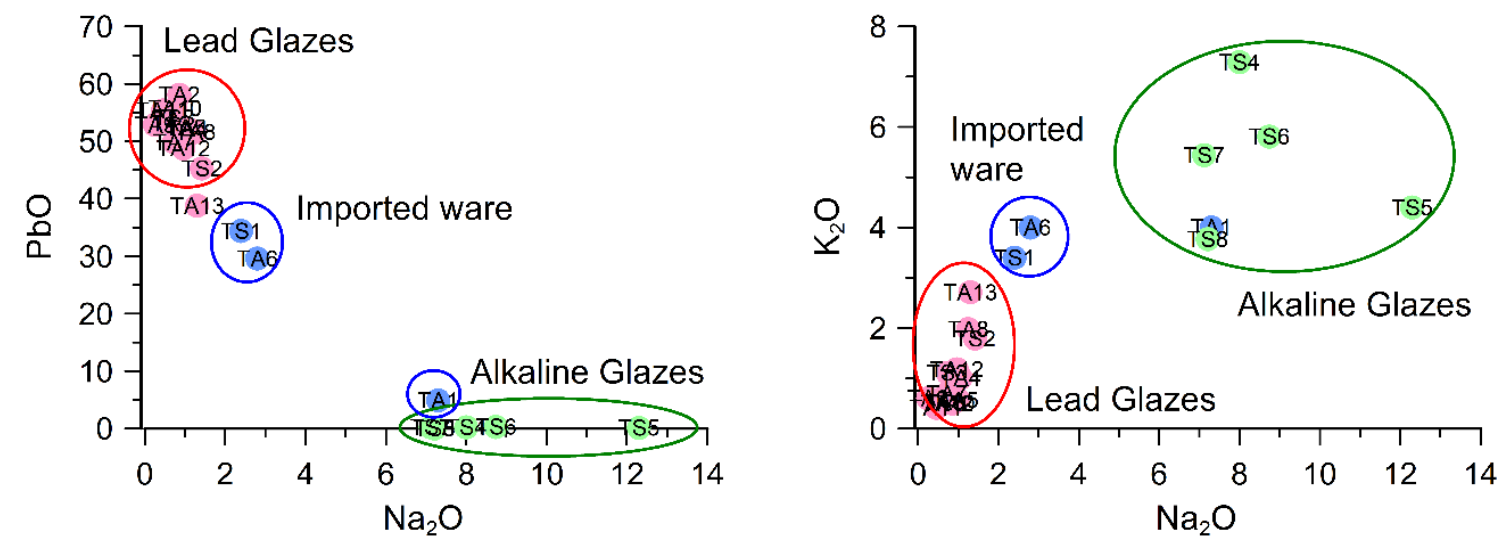

Fig. 3. Bivariant plots of chemical analysis of the ceramic glazes (TA and TS) from SEM-EDS data. Red circle: lead glazes; blue circle: imported wares; green circle: alkaline glazes 
Figure 4
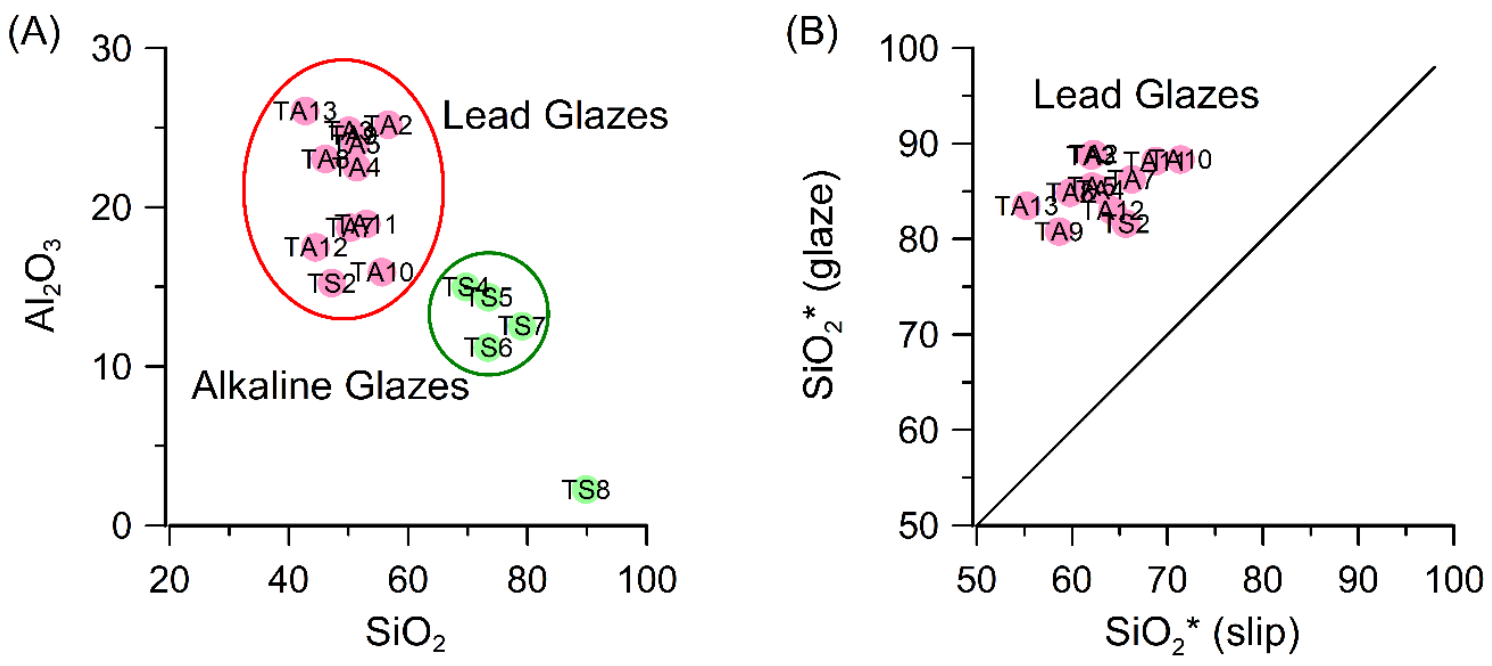

Fig. 4. (A) Bivariant plot of chemical analysis of the slips (TA and TS) from SEM-EDS data. Red circle: lead glazes; green circle: alkaline glazes (B) comparison between the $\mathrm{SiO}_{2}$ * of the glaze and of the slip after subtracting $\mathrm{PbO}$ and data normalizasion 

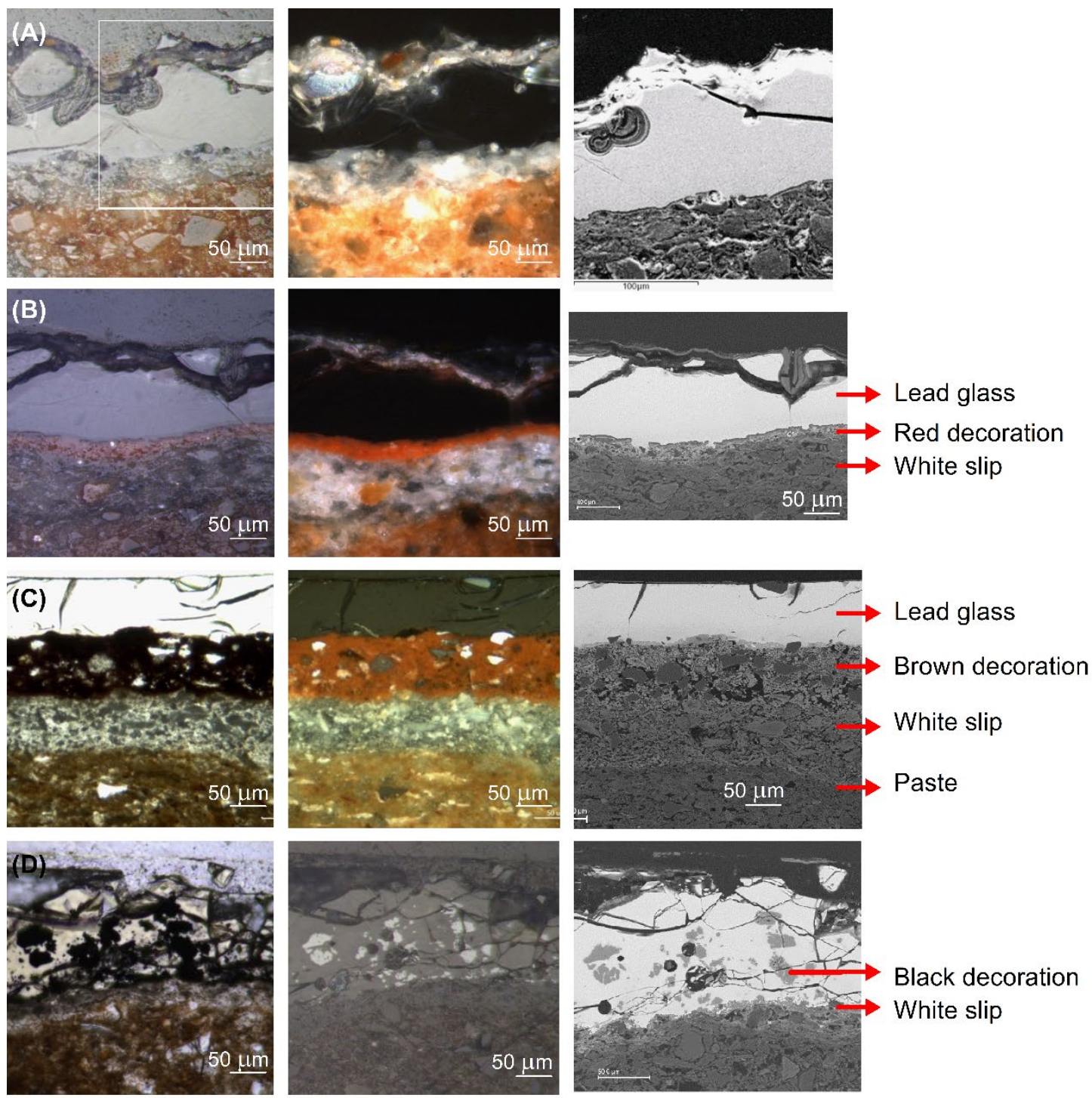

Fig. 5 From left to right optical microscope images in reflected light, polarised light, and BSESEM image from thin cross sections of (A) white slip and (B) red decoration of TA2, (C) brown decoration of TA3 and (D) black decoration of TA2 corresponding to iron oxides. 
Fig.6
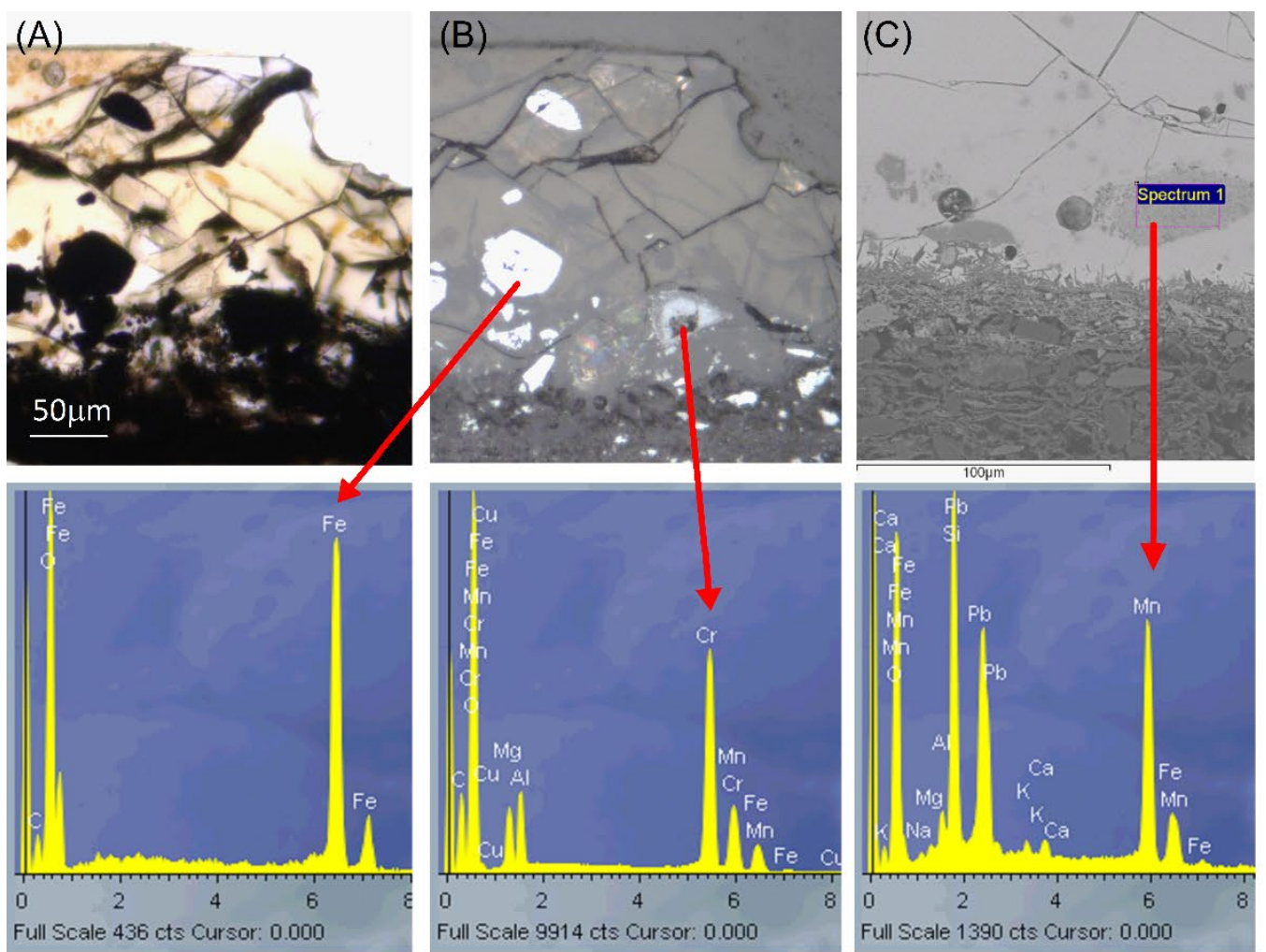

Fig. 6. (A) optical microscope images in transmission light, (B) reflected light, and (C) BSE-SEM image from thin cross sections from TA12. The black slip contains large particles of iron oxide, some particles of chromium spinel and partially dissolved manganese oxide particles. 

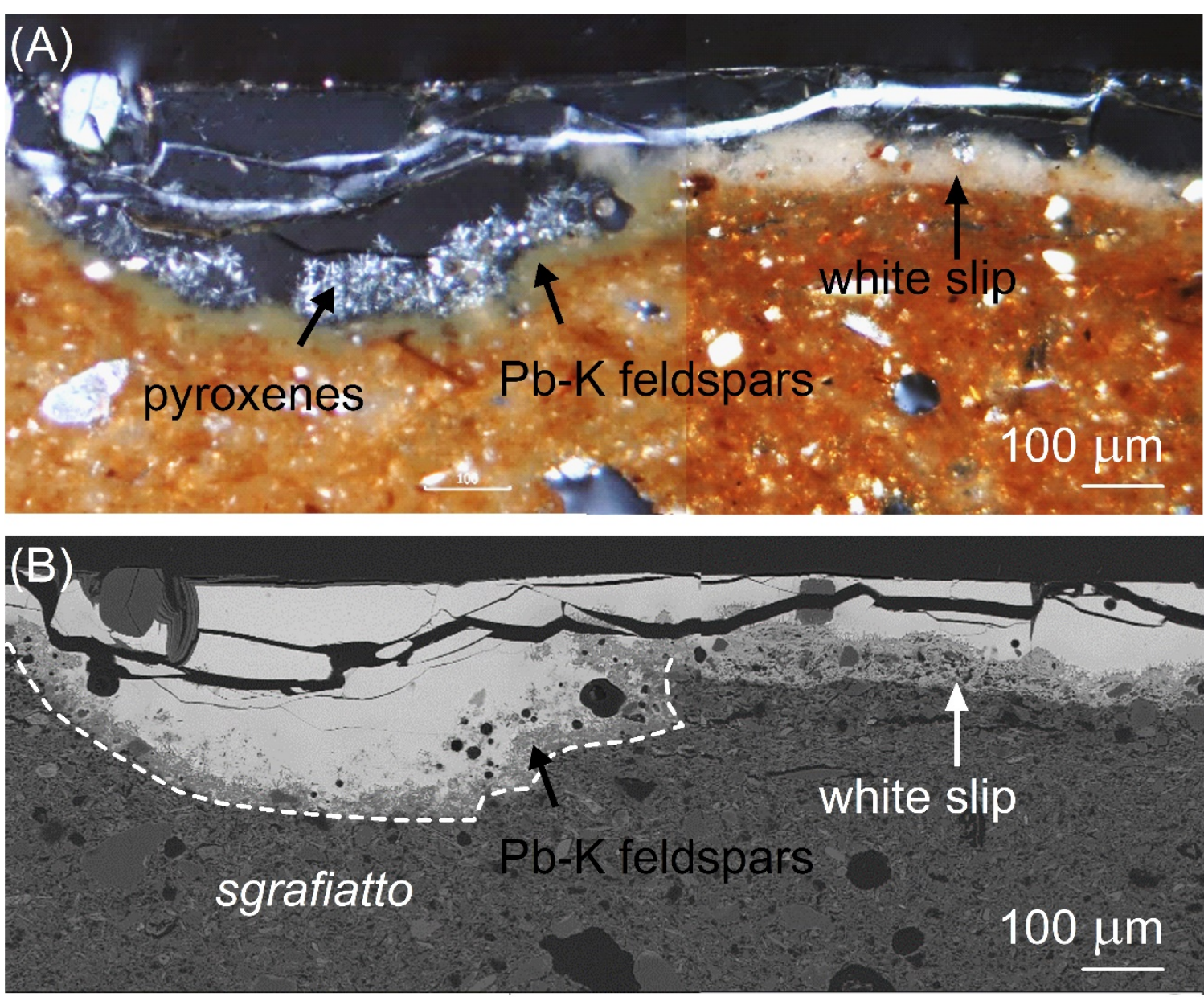

Fig. 7. (A) Optical image in reflected light and (B) BSE-SEM image of a thin cross section from sample TA7 showing the sgraffiato area. 
Fig. 8
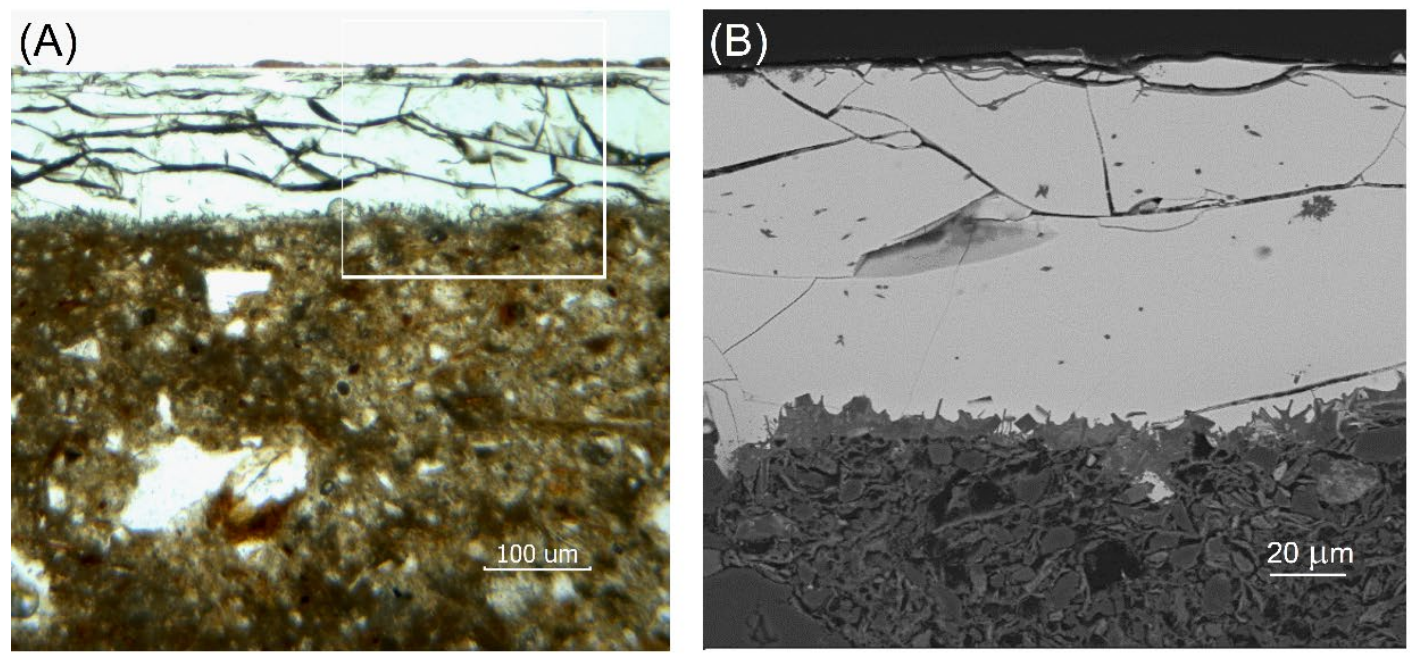

Fig. 8. (A) Optical image in reflected light and (B) BSE-SEM image of a thin cross section from sample TS3. 
Fig. 9
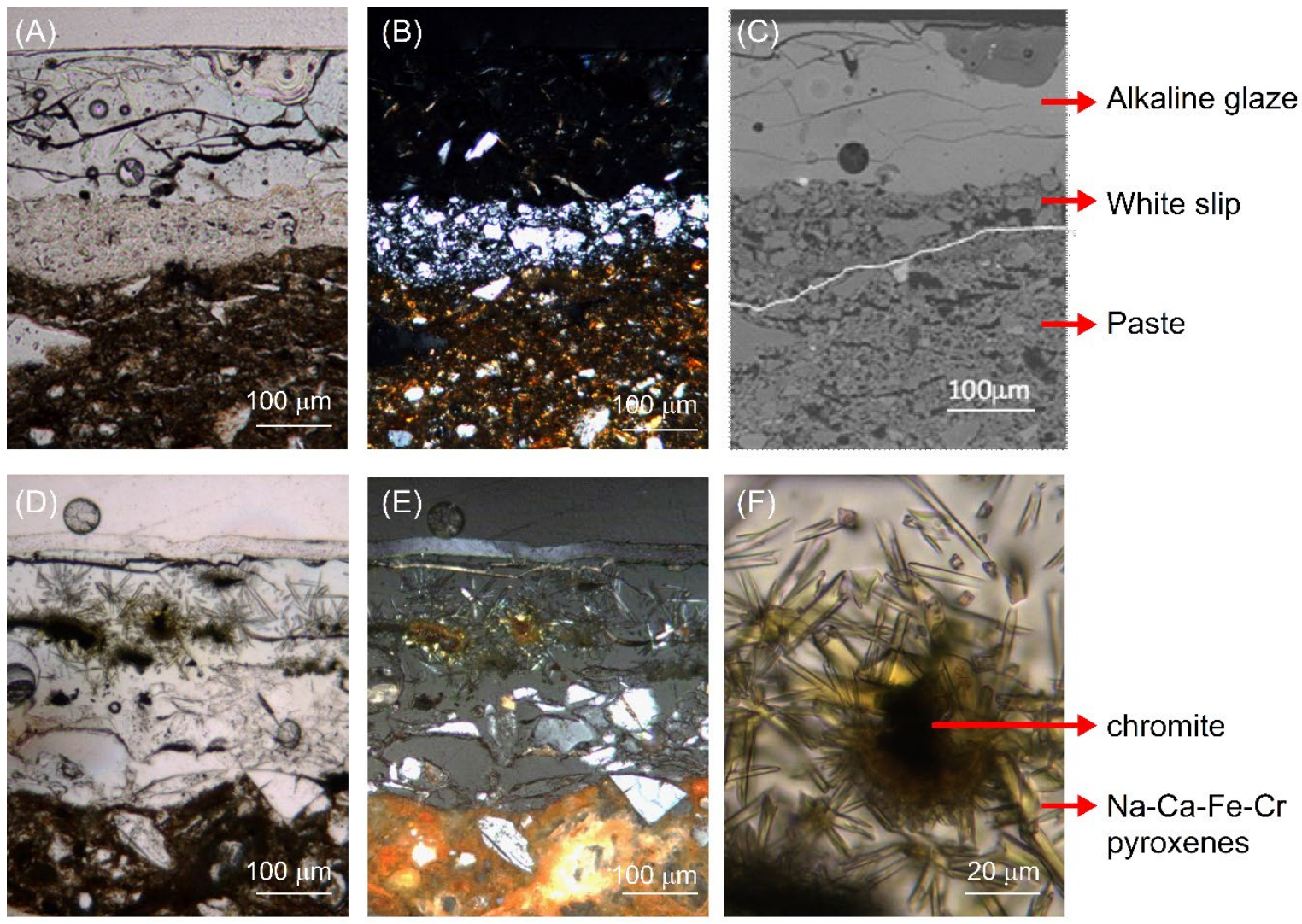

Fig. 9 (A) Optical image in transmission mode PPL (B), in reflection mode XPL, and (C) BSE-SEM image of a thin cross section from sample TS5. (E) Optical image in transmission mode, PPL (F) in reflection mode XPL of a thin cross section from sample TS8; (G) Optical image in transmission mode PPL of the black chromite and acicular yellow $\mathrm{Ca}-\mathrm{Fe}-\mathrm{Na}-\mathrm{Cr}$ pyroxenes of the decoration of sample TS8. 